Central European Review of Economics \& Finance

Vol. 24, No. 2 (2018), pp. 71-84

DOI: $10.24136 /$ ceref.2018.011

Received: 25 January 2018. Accepted: 3 April 2018

Marian ŻUKOWSKI ${ }^{1}$, Monika NOWAKOWSKA ${ }^{2}$

\title{
BREXIT: BENEFITS AND COSTS FOR THE UNITED KINGDOM - REFLECTIONS FOR OBSERVERS IN EUROPE
}

The withdrawal of the United Kingdom from the EU structures creates a new chapter in the history of the European integration. For the first time, after several decades of steady and secure functioning of the EU, a split occurs. Lofty ideas about creation of strong, coherent, wealthier and safer Europe lose in the competition with economic indicators and the national interest of the United Kingdom.

Brexit is an expression of the negative evaluation of the EU functioning by the British society. This opinion is grounded in difficulties of the EU with solving current economic, social and political problems of contemporary Europe, as well as in decreased cooperation among member states. The following most important reasons for Brexit should be mentioned: the uncontrolled inflow of immigrants, increased terror threat, loss of economic independence and national identity. It is also worth noticing the successful actions of rightwing politicians who used the situation to build their own vision of the state.

Consequences of Brexit shall affect both the United Kingdom and the EU member states but also non-EU countries. They shall have political, economic and social dimensions. However, at the current stage of the negotiations, it is difficult to predict all effects of the decisions taken. According to analysts, the UK shall incur financial losses, competitiveness of economy will decline, GDP will go down, political relations with neighbour states will deteriorate.

Brexit shall affect particularly these states which are close trade partners of the United Kingdom. Loss of the UK as one of the economic pillars of the EU shall influence the economic situation of the entire European Union. Brexit is also a crack in the EU image as an organization cherishing the values of solidarity and humanism. Individual interests of particular member states can be a contagious example.

Keywords: Brexit, European Union, political situation of Europe at the beginning of the $21^{\text {st }}$. JEL Classification Codes: F02, F36.

\footnotetext{
${ }^{1}$ Professor of Economics, PhD Habil., The John Paul II Catholic University of Lublin, Institute of Economics and Management.

${ }^{2}$ Assistant Professor, PhD, The John Paul II Catholic University of Lublin, Institute of Economics and Management.
} 


\section{Introduction}

The British voted for leaving the EU structures. The referendum on 23 June 2016 had 17410742 participants, that is $72.2 \%$ of eligible voters, among whom $51.9 \%$ voted for the UK's exit from the European Union (UIHaq, 2016). It should be noticed that the decision about leaving the EU was important for the British, which is confirmed by very high participation of citizens in the referendum. The decision about leaving the EU divided the society into two almost equal parts - only slightly more people voted for withdrawal from the EU than against. It seems that the result of the referendum was accurately commented by A. Glencross (2016): this was a defeat of Prime Minister David Cameron who wrongly evaluated people's moods, especially as regards the issues of immigration and trust in the ruling elite.

On 29 March 2017 the Government of the United Kingdom notified the European Council of the decision to leave the European Union. In the letter informing about this decision, Theresa May, Prime Minister of the UK, presented the key principles of the negotiation process on the national level and in the relations between the EU and the UK (Letter of the Prime Minister of the United Kingdom to the President of the European Council notifying the UK's decision to leave the EU, 2017). In connection with this decision, the European Council holds negotiations with the United Kingdom (Statement by the European Council (Art. 50) on the UK notification, 2017).

The commencement of Brexit has become a fact. Numerous questions arise to which we do not know answers yet. What shall be the conditions of the UK's withdrawal from the EU structures? What does Brexit mean for immigrants residing in the UK? What will be the future of the Union in view of the fact that one of its important members is leaving?

The following hypotheses can be put forward:

1. In the British literature there is an increasing number of studies juxtaposing the benefits and costs of Brexit. This does not pertain to government analyses, because there are no arrangements concerning formal rules of Brexit negotiated with the EU.

2. In the course of time, the number of ardent supporters of leaving the EU is declining in the UK, because the European Union has adopted the position of the absolute protection of its internal market.

The aim of this article is to analyse the anticipated benefits which the UK intends to obtain, as well as a possibility to secure the EU interests after Brexit. Presentation of the point of view of British scientists makes it possible to look at the problem from the perspective of those directly concerned. This enables a thorough and more objective evaluation of Brexit effects for the EU citizens.

The scientific method adopted by the authors at writing this article is the analysis of works published mostly in the UK. The authors' intention is to present the opinions of British researchers to the readers. Thus, the article fills the gap on the Polish market 
where studies by Polish researchers are predominant. Presentation of the British studies makes it possible to examine the issue of Brexit taking into account the opinions of the directly concerned British people.

The research hypotheses proposed, the scientific methods applied and the goal formulated determine the structure of the study. The historically developed model of the EU is presented, the contemporary problems which gave rise to the decision about Brexit are described, the costs and benefits which the British can derive from leaving the EU are enumerated. Moreover, the conclusions which may be drawn for the European Union are presented as the outcome of the research.

\section{The European Union - principles, goals, tasks}

Various attempts at political and economic integration in Europe were made already after the end of the World War II. We can mention, for instance: the Benelux Union, NATO, the Nordic Council, or the Council for Mutual Economic Assistance and the Warsaw Pact in Central and Eastern Europe. Several communities were also established: the European Coal and Steel Community (1951), the European Atomic Energy Community and the European Economic Community (1957) (Barcz, Kawecka-Wyrzykowska \& Michałowska-Gorywoda, 2016). It was assumed that an agreement concluded would help avoid armed conflicts in the Old Continent and would create an organization able to compete with other political and economic blocs in the world (Łastawski, 2004).

A new phase in the European integration process took place by virtue of the Treaty on European Union (the Maastricht Treaty) which provided for "ending the division of the European continent and creating firm bases for the construction of the future Europe" (Treaty on European Union, 2016). In this manner the European Union was established in 1993. Its fundamental principle was cooperation understood as the intention of the united countries to develop economy and social relations together and to pursue various non-economic goals.

Originally, the EU comprised three European Communities (first pillar), that is the European Community (formerly: the European Economic Community), the European Atomic Energy Community (Euratom) and the European Coal and Steel Community (which ceased to exist in 2002). The European Community played a significant role mainly in creation of the internal market with four freedoms: free movement of goods and workers, freedom of establishment and freedom to provide services, and free movement of capital, as well as in pursuing common policies (including trade and agriculture). The second pillar pertained to the Common Foreign and Security Policy, and the third pillar to the Police and Judicial Cooperation in Criminal Matters (Barcz et al., 2016).

By virtue of the Treaty of Lisbon, in 2009 the European Union was transformed into a uniform international organization. This is stipulated in Art. 47 of the Treaty on 
European Union (TEU) which provides that "the Union shall have legal personality" (Skolimowska, 2014). As a result of the adopted amendments, the institutional structure and the decision-making mechanism of the Union were made uniform and cohesion was reinforced. The pillar structure of the Union was abolished and the uniform Union regime was introduced (Barcz et al., 2016).

The aims of the European Union are specified in Art. 3 section 1 of TEU (Treaty on European Union, 2016). One of the most important goals is to create a single political body which would pursue common foreign policy on the international arena. This is supposed to increase security of member states, create an image of strong and coherent Europe and prevent wars and arguments between countries. The European Union supports economic, social and territorial cohesion and solidarity among its member states.

A goal of the European Union is to act for the sustainable development of Europe, based on balanced economic growth, stable prices, social market economy of high competitiveness aiming at full employment and social progress, as well as a high level of protection and improvement of quality of the environment. Furthermore, the Union establishes the internal market and the economic and monetary union whose currency is the euro.

The Union offers its citizens free movement of people. It combats social exclusion and discrimination and supports social justice and welfare, equality of men and women, solidarity between generations and protection of children's rights. The Union respects its rich cultural and linguistic diversity and takes care of safeguarding and development of the European cultural heritage (Treaty on European Union, 2016).

The European Union regularly increases the number of its members. Until 2004 the EU had 15 member states. In 2004 as many as 10 further states joined the Union, and in 2007 and 2013 - three more states. Currently, the European Union has 28 members.

\section{Contemporary problems as a reason for the UK's withdrawal from the European Union}

The European Union faces numerous political, social and economic problems which became particularly intensified in the 2 nd decade of the $21 \mathrm{st} \mathrm{c}$. One of the major difficulties is the refugee crisis from 2015-16 which caused enormous social and economic problems in the destination countries of the migration, such as Germany, France and the UK, but also in the countries where the greatest numbers of emigrants arrived first (Italy and Greece). This crisis erupted also in the countries through which emigrants travelled to the north and west of Europe (Hungary, Serbia, Croatia, Austria, France). It turned out that the scale of difficulties encountered by the states affected by this situation frequently exceeded their ability to cope with the circumstances on an ongoing 
basis. In the years 2015-2016 more than a million of refugees and immigrants arrived in the EU (European Commission, EU and the refugee crisis, 2016).

Furthermore, based on the principle of free movement of workers in the EU, a huge number of people came to the UK, especially after the enlargement of the Union in 2004 and 2007. This produced various effects, including considerably increased reluctance to newcomers in certain social groups (Garapich, 2016). The total number of immigrants in the UK grew from 1345000 in 1990 to almost three million in 2015 (Barbone, Green, Speckesser, \& Broughton, 2017). The numbers presented by the Office for National Statistics in May 2016, that is a month before the referendum, showed that the net migration grew to 333000 people in 2015 - this was the second highest result in history (UlHaq, 2016).

These migration-related circumstances triggered two significant political phenomena. Firstly, right-wing, nationalist and Eurosceptic parties used a growing anxiety among large social groups in the EU countries for their own purposes of fighting for power. In the UK, the United Kingdom Independence Party (UKIP), voicing the intention to break the relationships with the EU, gained much in popularity. The party activists fuelled the concerns that migrants would enter the local labour market and worsen the accessibility of public services (mostly social benefits, especially in education and in health care) (UIHaq, 2016). The referendum with the proposal of the UK's withdrawal from the EU should be regarded as this party's success (Garapich, 2016). As it turned out later, the arguments used against immigrants were not always true - but the intended results were achieved.

Secondly, difficulties connected with ongoing and efficient management of problems brought by the migration wave led to various attitudes of particular states, not always consistent with the principle of solidarity and cohesion within the Union (Fehler, Cebul, \& Podgórzańska, 2017; Janik, \& Jaremczuk, 2017). A group of wealthier states could be distinguished which directly experienced the migration problem and which tried to absorb the incoming masses of migrants. This policy was justified with humanitarian or socioeconomic reasons. On the other hand, many less affluent countries, mainly from Central and Eastern Europe, tried to protect their citizens against possible effects of the influx of immigrants, taking into account the aspects of security and living standards of inhabitants. Between these two groups of states there have been political tensions and mutual criticism of their respective policies towards the migration movement.

In the context of these processes, the relationship between the UK and the EU was described as "a married couple who do not cooperate". The UK curbed the idea of the EU's solidarity, which was inconsistent with the guiding principles of the Union (UIHaq, 2016). At the time when the UK co-created the European Union, it had 9 member states. Currently, there are as many as 28 members, and 5 more states (Albania, Macedonia, Montenegro, Serbia and Turkey) apply to join the EU structures. Altogether these are already almost 90 million of new citizens (Gietel-Basten, 2016). 
A problem arousing the resistance to absorption of immigrants is a lower rate of economic growth than in the previous decades (and sometimes recession) in the EU countries and a related higher unemployment rate which is currently running over $8 \%$ (Eurostat. Unemployment rate-total, 2017). This is largely due to the economic crisis which started in 2008 in the USA but quickly reached Europe and hampered the development of economy in many countries of the continent. The crisis aggravated the discrepancies in the socioeconomic growth rate between particular states. This context is important despite the fact that GDP has been growing and unemployment rate has been decreasing in the EU states in the last two years.

As demonstrated by the research conducted in Great Britain, customs and habits which form the national identity of this country's citizens have been increasingly regarded as more important than expectations connected with a need for European integration in the recent years. Moreover, as right-wing politicians claim, the EU interests pursued have not always contributed to the efficient functioning of the British economy or sovereignty of the islands (Parlett, 2016).

According to British researchers, the main factors in favour of the UK's withdrawal from the Union were: negative attitudes of citizens towards the uncontrolled immigration wave, increased terror threat, deteriorated economic situation and losing of the national identity (Clarke, Goodwin, \& Whiteley, 2017).

\section{The EU leaving procedure}

Pursuant to Article $50 \mathrm{TEU}$, any member state can decide to leave the Union (Treaty on European Union, 2016). The basis for "voluntary withdrawal from the Union" is an international agreement which specifies the conditions of withdrawal and the form of future relations between the leaving state and the Union. The procedure of voluntary withdrawal from the EU means that other opportunities based on the general international law have been excluded, thus unilateral exit from the EU is not possible. The aforementioned article describes also the mechanism "enforcing" negotiations of the agreement. In the event the agreement does not enter into force within two years since the notification of the withdrawal decision (this deadline can be extended), the decision becomes effective. A state which left the Union and wants to join the EU again needs to follow the normal accession procedure (Barcz et al., 2016).

In the case of Brexit the procedure specified in Art. 50 TEU was applied. Pursuant to this Article, a member state which takes a decision about leaving the EU notifies the European Council of this intention. The agreement is negotiated in accordance with the guidelines of the European Council (Art. 218 section 3 of the Treaty on the Functioning of the EU) and then signed by the Council on behalf of the Union, based on the qualified majority of votes ( $72 \%$ of the voting states, except for the UK), after obtaining prior 
consent of the European Parliament (Brexit - procedural aspects as at 20.06.2017, 2017; Miller, Lang, \& Caird, 2017).

On 24 January 2017 the Supreme Court of the United Kingdom issued a decision that the process of the UK's withdrawal from the EU can be commenced after prior consent of the British Parliament (Brexit explained. Article 50 Bill, 2017). On 13 March 2017 both chambers of the British Parliament passed an act authorizing the Prime Minister Theresa May to begin negotiations over UK's withdrawal from the EU.

Pursuant to Art. 50 section 2 TEU, the formal procedure of leaving the EU was commenced on 29 March 2017 upon notification to the European Council of the UK's decision to leave the EU. On 29 April 2017 the European Council adopted negotiation guidelines concerning Brexit (Brexit - procedural aspects as at 20.06.2017, 2017) and on 19 June 2017 the negotiation procedure was opened. The parties agreed on the basic principles of conducting negotiations, including establishment of three negotiation groups: for citizens' rights, for financial settlements and for other issues connected with the exit. Moreover, a dialogue on the status of Ireland/Northern Ireland was begun (Terms of Reference for the Article 50 TEU negotiations, 2017). The negotiations have started and they constantly reveal new problems. Each party is looking for ways to advance its interests and to shun troubles brought up by the other party.

\section{Cost and benefits of leaving the EU for the British}

According to Brexit advocates, the UK's withdrawal from the Union shall bring economic, social and political benefits. As regards economic issues, it will offer a better position in negotiations of mutual trade agreements. It should be emphasized that the UK is the largest trade partner of the EU. The British economy shall no longer be limited by the EU law and regulations (Baker, \& Schnapper, 2016). The costs of implementation of the EU regulations amounted to ca 30 billion GBP per year. Some of this money could be allocated to health care reform, financing of education or development of transport. Moreover, the UK's independence from the Union means reduction in costs of crises in the euro area absorbed by the EU states not belonging to the monetary union (Garapich, 2016).

On the other hand, Brexit means considerable uncertainty and instability in trade relations with the EU. Economists predict that the UK's international trade will decline, which will lead to lower standard of living in the country. Exit from the Union will cause a drop in British national income. Some financial analysts claim that it will decrease by $1.3 \%-2.6 \%$ in comparison to the level before leaving the EU (that is by around 850 to $1700 \mathrm{GBP}$ per household) (Garapich, 2016). According to the research carried out by Axa Investment Managers (Axa IM), costs of Brexit shall lead to a decline in GDP by 2-7\% according to the optimistic prognosis or by ca $14 \%$ in the pessimistic version (see Table 1). 
Table 1. Estimated cost of the UK's exit from the EU - scenarios

\begin{tabular}{|l|c|c|c|}
\hline & Optimistic version & Pessimistic version & Probable version \\
\hline Trade relationship & 1.6 & -9.5 & -3 to -7 \\
\hline Regulation & 5.0 & -1.7 & 1 to -1 \\
\hline Budget & 5.6 & 2.2 & 3 to 4 \\
\hline Migration & 0.0 & -5.0 & -1 to -3 \\
\hline Total impact & 12.2 & -14.0 & -2 to -7 \\
\hline
\end{tabular}

Source: Morrissey, H. (2016, February 11). Calculating the cost of Brexit. Professional Pensions (London), p. 18 (based on AXA IM Research).

Experts estimate that Brexit will cost the UK ca 60 bln EUR. This amount comprises mostly unpaid budget liabilities, described as "reste á liquider" ("outstanding commitments"), funds for investment expenses approved for 2014-2020 and pension commitments for EU officers (Barker, 2017; Tutty, 2017; Malacain, 2017).

Depending on the solutions adopted between the EU and the UK - Brexit can have a "soft" form, with remaining on the single market and a liberal attitude to immigrants, or a "hard" form, that is leaving the single market completely and a strict policy towards immigrants, also those coming from the European Union.

London is an international financial centre, rendering services to European and global clients. Hard Brexit would result in partial migration of financial companies from London to the EU27. According to estimates, about $35 \%$ of wholesale market activities and 30 000 people can move from London to other main cities of the EU (Batsaikhan, Kalcik, \& Schoenmaker, 2017).

On the other hand, the share of British turnover in foreign currencies (of all countries and all products) accounted for ca $37 \%$ in 2016. As regards three main currencies (USD, EUR and JPY), the UK is the largest market, more than twice as big as the USA (Batsaikhan et al., 2017).

After leaving the EU, the UK should pay to the EU budget 14.5 bln GBP (ca 16.9 bln EUR) which corresponds to the net contribution which the UK ought to pay in 2019 and 2020 if it still were an EU member state. Moreover, the UK will not receive agricultural subsidies and will lose money for infrastructure transferred by the EIB (Barker, 2015).

An important issue raised by Brexit supporters which shall be regulated is the issue of immigrants and refugees. Migration is connected with economic, cultural, demographic and security issues in view of contemporary terror acts. The government will be able to control a flow of people from the European Economic Area more effectively than today (Owen, 2017).

It should be noted that the Eurosceptical British politicians tried to renegotiate the principle of free movement of people from the EU but they encountered strong opposition from the EU leaders. The issue of welfare benefits for immigrants was publicized in 
the media (despite doubtful methodology of presenting statistical data) and depicted as a serious burden on the British budget (Garapich, 2016).

Nevertheless, it turned out that only one-third of foreigners receiving welfare benefits in 2015 were EU citizens (Garapich, 2016). Despite an increase in expenses (on social welfare and health care) by more than $200 \%$ in the years $2005-2015$ for EU citizens: from 3194 million EUR to 9888 million EUR, the Union's citizens contributed to the UK economy more than they received (Barbone et al., 2017).

Thus, macroeconomic data demonstrate that net migrations have no great effect on the economy (Garapich, 2016). However, a stricter migration policy towards EU citizens can affect these sectors of the British economy which have been dominated by cheap labour force from the EU countries. This can lead to a shortage of employees in some sectors of the economy. Nevertheless, the impact of European migrations as a result of Brexit is difficult to estimate owing to the correlations which are yet to be revealed (Garapich, 2016).

Brexit is also supposed to restore the national identity, so emotionally presented in the British press, as the EU interests not always served the sovereignty of the British nation. Theresa May emphasized that when immigration is too high and a rate of change too fast, it is impossible to build a coherent and stable society (Theresa May's speech, 2015). British Eurosceptics believe in the unique quality of the political institutions functioning in the UK which enabled creation of individualism, pluralism and freedom guaranteed by law (Piotrowski, 2015). These values are important and attractive enough not to be belittled.

The principle that solidarity of the EU states should prevail over autonomy of national parliaments has been criticised in recent debates (Parlett, 2016). However, the slogans about restoring UK's sovereignty can also awaken the dormant emotions. Politicians from the Scottish National Party (SNP) claim that the UK's exit from the EU shall alter the relations between England and Scotland and shall lead to another voting on Scotland's independence. Thus, it can result in disintegration of the state. Moreover, the Irish government warns that Brexit can hamper the Northern Ireland peace process (Garapich, 2016).

\section{Brexit - conclusions for other countries}

Brexit has aroused many emotions and has posed numerous questions both to the UK and to the EU member states. However, today it is difficult to answer the most important of them: what shall be the impact of the UK's withdrawal from the Union. Certainly, Britain's absence in the EU will lead to major consequences in the economic, political and social aspects. 
First of all, the EU's political and military force shall decrease because the UK was one of the most important EU member states and spent on the army significant sums of money: 57 bln USD in 2013 (Pawlas, 2016).

The economic situation looks a bit different. Brexit will cause a decline in the economic potential because, according to experts, the EU's GDP shall go down by $17.5 \%$, export of goods shall decrease by $23 \%$ and a share of trade services shall drop by almost $38 \%$. Brexit entails a drop in the EU's GDP by ca 2.5 trillion EUR (Pawlas, 2016) and a decrease in the number of consumers on the single market by about 66 million people (Eurostat. Population on 1 January 2017). The number of consumers shall not go down if the UK successfully negotiates its further participation in this market (Proceedings of the workshop on the consequences of Brexit, 2017). However, according to many economists, the EU will not have problems with effective functioning after Brexit (Pawlas, 2016). Nevertheless, the net EU budget shall decrease because the UK paid 18.2 bln EUR to the EU (in 2015) and received far less: 7.5 bln EUR (EU expenditure and revenue 2014-2020). The UK has a net share in the EU budget at a level of ca $7 \%$ (Eurostat. EU expenditure and revenue 2000-2015). Brexit shall result in a necessity for higher payments to the EU budget by other states and/or reduction in some planned expenses. It is estimated that the revenue of the EU member states shall decrease by 12 to 28 bln GBP (Garapich, 2016).

It is supposed that the four big cities: Frankfurt, Paris, Dublin and Amsterdam will become the centres of most new wholesale markets of the EU27. Thus, a partial migration of financial companies will have a considerable influence on these cities and their infrastructure. Financial transactions (Forex, securities and the derivatives market) shall be moved from London to the EU, which is supposed to result in a significant increase in the EU's trade potential (Batsaikhan et al., 2017).

The conclusions which can be formulated as a result of Brexit are the following: The UK's withdrawal from the EU will especially affect these countries with which the UK has been strongly connected economically or politically. These countries include primarily Ireland, as well as Sweden, Poland and the Netherlands. On the other hand, Italy is concerned that Brexit shall be significantly reflected in worse balance of trade and unemployment growth in this country. Moreover, the EU will lose benefits connected with extensive relations of Great Britain with non-EU states, such as: Australia, New Zealand, Singapore, Japan and China (Möller \& Oliver, 2014).

Great Britain was a destination country for a large numbers of educated and cheap labour force from the less developed EU states, especially from the Central and Eastern Europe: Poland, Lithuania, Romania or Bulgaria. On the other hand, the British currently residing in Spain and Malta are worried about the stability of their further functioning in these countries (Ceallaigh, 2017).

Brexit takes place at a difficult moment in history. The European Union goes through a serious internal crisis. A financial and economic slump, lasting for several years, and 
conflicts between the EU member states show that cooperation is functioning poorly in many areas: in the economic, social, political and cultural aspects. The principles and mechanisms of operation of the EU practices raise many objections and need to be changed (Fiszer, 2016).

Brexit has strengthened an intention of the leaders of "old" and affluent Union to build "two-speed Europe" (Sapieżko-Samordak, 2016), announced in March 2017 in the form of the so-called Versailles declaration. This idea consists in acceptance of various pace of integration of particular member states. This is supposed to lead to further integration of rich Western countries, such as France and Germany. Other member states can be made subordinate to the European leaders, otherwise they may find themselves outside the centre of taking strategic EU decisions. This undermines the European solidarity which became the basis for the Union's creation, diversifies the position of particular states, and generates a risk of marching at a different pace (Kołodziejski, 2017).

These tendencies have been strongly emphasized by British economists who claim that the EU is not flexible in the talks with other member states. A refusal to take into account the concerns of member states puts the EU's future at risk because aspirations to larger freedom and autonomy are growing in many European countries. Directives adopted by the EU have to take into consideration the needs of particular member states (UlHaq, 2016).

However, we can consider that the UK's withdrawal from the EU will strengthen the cohesion of the EU member states (Kokotovic \& Kurecic, 2017). Brexit shall speed up integration, in accordance with the declaration: "Greater European Integration: The Way Forward", signed together by the presidents of the European countries. The process of reaching joint decisions will probably become easier and faster, because the UK frequently obtained opt-out clauses infringing the EU's uniformity (Cremades \& Novak, 2017). On the other hand, lack of the UK acting as a brake in the EU can lead to problems with taking right decisions by the Union.

The strength of the European Union in the 21 st $\mathrm{c}$ depends on many variables. Its future shall be built through creation of the joint European identity and efficient functioning of the European institutions. Hence, four scenarios of the EU development can already be constructed: stagnation, evolution towards a superstate with Germany and France as the leaders, evolution towards specialization, and stratification of the EU (Szumowski, 2015). Currently, we have learned that there is yet another, fifth possibility - leaving the EU structures by each state.

Thus, Brexit is a difficult challenge to the Union itself, which needs to be faced. If the major states of the EU draw accurate conclusions from that and give an impulse for modernization of the EU structures in terms of flexibility, increasing the power of member states and national parliaments, democratic accountability and justice, then the European Union can become consolidated and strong. Otherwise, another split and weakening may occur. 
Nevertheless, Brexit is the most difficult challenge to the United Kingdom. The UK wants to make use of its political and economic autonomy in the long-term perspective. However, it will need to build its relations right from the beginning. Will the sum of benefits exceed the sum of losses? It will turn out already in a few years. We can wish the United Kingdom good luck.

\section{References}

Baker, D., \& Schnapper, P. (2015). Britain and the crisis of the European Union. Basingstoke: Palgrave Macmillan.

Barbone, L., Green, M., Speckesser, S. \& Broughton,A. (2017, January). Brexit implications for employment and social affair. Facts and figures, Brussels. Directorate General for Internal Policies. Policy Department A: Economic and Scientific Policy. Retrieved July 25, 2017, from: http://www. europarl.europa.eu/RegData/etudes/STUD/2017/595333/IPOL_STU(2017)595333_EN.pdf

Barcz, J., Kawecka-Wyrzykowska, E., \& Michałowska-Gorywoda, K. (2016). Integracja europejska w okresie przemian. Aspekty ekonomiczne. Warszawa: Polskie Wydawnictwo Ekonomiczne.

Barker, A. (2017, February). The $€ 60$ billion Brexit bill: How to disentangle Britain from the EU budget. Policy Brief, Centre for European Reform. Retrieved September 19, 2017, from: http:// www.cer.eu/sites/default/files/pb_barker_brexit_bill_3feb17.pdf

Batsaikhan, U., Kalcik, R., \& Schoenmaker, D. (2017). Brexit and the European financial system. Policy Contribution, 4, 1-13. Retrieved September 19, 2017, from: http://bruegel.org/wp-content/uploads/2017/02/PC-04-2017-finance-090217-final.pdf

Brexit-aspekty proceduralne wg stanu na 20.06.2017. (2017). Retrieved August 25, 2017, from: http://oide.sejm.gov.pl/oide/images/files/pigulki/brexit_2.pdf

Brexit explained. Article 50 Bill. (2017). London: Institute for Government. Retrieved July 25, 2017, from: https://www.instituteforgovernment.org.uk/sites/defaultfiles/publications/article50-bill.pdf

Ceallaigh D. Ó (ed.). (2017, May). Brexit. A Status Report. Second edition. Dublin: Institute of International and European Affairs. Retrieved September 18, 2017, from: http://www.iiea.com/ $\mathrm{ftp} /$ Publications/2017/BrexitStatusReport_26May.pdf

Clarke, H. D., Goodwin, M., \& Whiteley, P. (2017, February). Why Britain voted for Brexit: an individual-level analysis of the 2016 referendum vote. Parliamentary Affairs. Retrieved July 25 , 2017, from: http://kar.kent.ac.uk/60902/

EU expenditure and revenue 2014-2020. (2017). Retrieved September 19, 2017, from: http:// ec.europa.eu/budget/figures/interactive/index_en.cfm

European Commission (Directorate-General for Communication). (2016). UE a kryzys uchodźczy, Luxembourg: Publications Office. Retrieved August 23, 2017, from: http://publications.europa. eu/webpub/com/factsheets/refugee-crisis/pl/

Eurostat. EU expenditure and revenue 2000-2015 data download. (2015). Retrieved September 30, 2017, from: internet-tables-2000-2015.xls 
Eurostat. Population on 1 January 2017. (2017). Retrieved September 30, 2017, from: http:// ec.europa.eu/eurostat/tgm/table.do?tab=table\&init=1\&language=en\&pcode=tps $00001 \&$ plugin $=1 \mathrm{http}: / /$ ec.europa.eu/eurostat/tgm/table.do?tab=table\&init=1\&language=en\&pcode=tps0000 1\&plugin=1

Eurostat. Unemployment rate-total. (2017). Retrieved September 25, 2017, from: http:// ec.europa.eu/eurostat

Fehler, W., Cebul, K., \& Podgórzańska, R. (2017). Migracje jako wyzwanie dla Unii Europejskiej i wybranych państw członkowskich. Warszawa: Difin.

Fiszer, J. M. (2016). Wady i zalety członkostwa w Unii Europejskiej oraz nowe wyzwania dla polityki integracyjnej Polski. Politeja 4(43), 181-215.

Garapich, M. P. (2016). Brexit - fakty, mity, liczby. Możliwe konsekwencje wystapienia Wielkiej Brytanii z Unii Europejskiej. Analiza głównych osi debat publicznych. Warszawa: Fundacja Instytut Spraw Publicznych. Retrieved July 25, 2017, from: http://www.feswar.org.pl/fes2009/e-books/Brexit.pdf

Gietel-Basten, S. (2016, December). Why Brexit? The toxic mix of immigration and austerity. Population and Development Review, 42, 4, 673-680.

Glencross, A. (2016). Why the UK voted for Brexit: David Cameron's great miscalculation. London: Palgrave Macmillan.

Janik, W. J., \& Jaremczuk, E. J. (2017). Artykuł wprowadzający. Niekontrolowana migracja jako zagrożenie dla Europy - polski strach przed uchodźcami. W: E. J. Jaremczuk (red.), Migracje i kryzys uchodźczy w Europie. Rzeczywistość i wyzwania (s. 11-68). Poznań: FNCE.

Kokotovic, F., \& Kurecic, P. (2017, Mart). The case of Brexit: an analysis of the political and economic factors. Journal of Economic and Social Development, 4(1), 28-39.

Kołodziejski, K. (2017, September). Europa na wirażu. Gazeta Bankowa, 10-14.

Łastawski, K. (2004). Od idei do integracji europejskiej, od najdawniejszych idei do Unii 25 państw. Warszawa: Wydawnictwo Wyższej Szkoły Pedagogicznej TWP.

List Premier Zjednoczonego Królestwa do przewodniczacego Rady Europejskiej notyfikujacy decyzję o wystapieniu z UE. (2017). Retrieved August 25, 2017, from: http://oide.sejm.gov.pl/ oide/images/files/pigulki/brexit_dokumenty.pdf

Malacain, M., (2017, May 17). Brexit and the EU budget. Synthesis, Notre Europe - The Jacques Delors Institute. Retrieved September 19, 2017, from: http://www.institutdelors.eu/media/brexitandeubudget-synthesisseminar-may2017.pdf?pdf=ok

Miller, V., Lang, A., \& Caird, J. S. (2017). Brexit: how does the Article 50 process work?, Briefing Paper, 7551. House of Commons Library. Retrieved August 25, 2017, from: http://researchbriefings.parliament.uk/ResearchBriefing/Summary/CBP-7551\#fullreport

Möller, A. \& T. Oliver, T. (ed.). (2014). The United Kingdom and the European Union: What would a "Brexit" mean for the EU and other States around the World?. Berlin: Deutsche Gesellschaft für Auswärtige Politike.V.

Morrissey, H. (2016, February 11). Calculating the cost of Brexit. Professional Pensions (London), 18-19. 
Oświadczenie Rady Europejskiej (art. 50) w sprawie brytyjskiej notyfikacji. (2017). Retrieved August 25, 2017, from: http://www.consilium.europa.eu/pl/press/press-releases/ 2017/03/29-euco-50-statement-uk-notification/

Owen, J. (2017). Implementing Brexit. Immigration. London: Institute for Government. Retrieved July 25, 2017, from: https://www.instituteforgovernment.org.uk/sites/defaultfiles/publications/ Brexit_immigration_WEB.pdf

Parlett, J. (2016). Brexit. London: Bluebird.

Pawlas, I. (2016). Brexit as a challenge for the European Union. Horyzonty Polityki, 7, 20, 57-76.

Piotrowski, P. (2015). Wielka Brytania a Europa. Torysi wobec integracji europejskiej. W: B. Gaziński (ed.), Szkice europejskie. Unia Europejska wobec wyzwań współczesności, (pp. 29-45). Olsztyn: Instytut Nauk Politycznych Uniwersytetu Warmińsko-Mazurskiego 2015.

Proceedings of the workshop on the consequences of Brexit, Brussels, 28 February 2017. (2017, June). Brussels: Directorate General for Internal Policies. Policy Department A: Economic and Scientific Policy. Retrieved September 9, 2017, from:http://www.europarl.europa.eu/RegData/ etudes/STUD/2017/602052/IPOL_STU(2017)602052_EN.pdf

Sapieżko-Samordak, J. (2016). Wzmocniona współpraca w Unii Europejskiej. Koncepcja, doktryna, praktyka. Warszawa: Elipsa.

Skolimowska,A. (2014). Unia Europejska jako organizacja międzynarodowa. Warszawa: CeDeWu.

Szumowski, A. (2015). Siła Unii Europejskiej w XXI wieku - perspektywy. W: E. Lesiewicz (red.), Zmieniająca się Unia Europejska. Wybrane aspekty polityczne i społeczno-gospodarcze (s. 77-90). Poznań: Wydawnictwo Naukowe WNPiD UAM.

Tell, C. M., \& Novak, P. (2017). Brexit and the European Union: general institutional and legal considerations. Brussels: Directorate General for Internal Policies of the Union. Policy Department for Citizens' Rights and Constitutional Affairs. Retrieved September 19, 2017, from: http://www. europarl.europa.eu/RegData/etudes/STUD/2017/571404/IPOL_STU(2017)571404_EN.pdf

Terms of Reference for the Article 50 TEU negotiations. (2017, June 19). Retrieved August 25, 2017, from: https://ec.europa.eu/commission/sites/beta-political/files/eu-uk-art-50-terms -reference_agreed_amends_en.pdf

Theresa May's speech to the Conservative Party Conference. (2015). Retrieved August 31, 2017, from: http://www.independent.co.uk/news/uk/politics/theresa-may-immigration-policiesspeech-conference-2015-tory-conservative-party-views-a7209931.html

Traktat o Unii Europejskiej (wersja skonsolidowana), (2016). Retrieved September 23, 2017, from: $h$ ttp://oide.sejm.gov.pl/oide/index.php?option=com_content\&view=article\&id=1480

Tutty, M. G. (2017, June 8). The Potential $€ 60$ billion cost to the UK of exiting the EU, The Institute of International and European Affairs (IIEA). Retrieved September 19, 2017, from: http://www. iiea.com/ttp/Publications/IEA\%20-\%20Brexit\%20Bill\%20paper\%20-\%20MGTutty.pdf

UIHaq A. (2016). A short guide to Brexit. Our divided future. [Bloomington]: Author House UK. 